Penelitian

\title{
Hemogram dan Respon Jaringan Hernia Insisional Babi Pascaterapi Mesh Bedah Polipropilen dengan atau tanpa Asam Hyaluronat
}

\author{
(Haemogram and Tissue Respons in Incisional Hernia of Pig Post Therapy \\ by Polypropylene Mesh With or Without Hyaluronic Acid) \\ Heryudianto Vibowo ${ }^{1}$, Gunanti ${ }^{2}$, Eva Harlina ${ }^{3}$ \\ 'Sekolah Vokasi IPB, Jalan Kumbang No 14, Bogor 16151 \\ ${ }^{2}$ Divisi Bedah dan Radiologi, Departemen Klinik Reproduksi dan Patologi \\ ${ }^{3}$ Divisi Patologi, Departemen Klinik Reproduksi dan Patologi \\ *Penulis untuk korespondensi: gunanti.soe@gmail.com \\ Diterima 7 Agustus 2018, Disetujui 28 Juni 2019
}

\begin{abstract}
ABSTRAK
Penggunaan mesh menjadi metode yang penting untuk terapi perbaikan hernia abdominalis karena dapat menurunkan angka kejadian hernia berulang dibandingkan dengan penggunaan metode penjahitan. Tujuan penelitian ini untuk mempelajari gambaran darah dan respon jaringan hernia insisional babi yang diterapi dengan mesh komposit dan polipropilen dengan atau tanpa asam hyaluronat secara histopatologi. Penelitian menggunakan babi sebanyak 11 ekor berumur 3-4 bulan yang dibagi menjadi 3 kelompok. Kelompok pertama mendapatkan mesh komposit (Physiomesh $^{\circledR}$ ), kelompok kedua mendapatkan mesh polipropilen (Ultrapro ${ }^{\circledR}$ ) yang diberikan asam hyaluronat (Guardic ${ }^{\circledR}$ ), dan kelompok ketiga mendapatkan mesh polipropilen (Ultrapro ${ }^{\circledR}$ ). Penelitian dimulai dengan menginduksi hernia setelah itu dilakukan pemasangan mesh, permanenan jaringan dan mesh, dan pembuatan preparat histopatologi. Hasil penelitian menunjukan tidak adanya perbedaan yang nyata pada gambaran darah complete blood count antar kelompok. Hasil penelitian gambaran sel radang di jaringan juga tidak menunjukan perbedaan yang nyata kecuali hasil pengujian paired T-Test untuk makrofag pada kelompok mesh polipropilen. Sedangkan pada pengujian One-Way Annova tidak memberikan hasil yang berbeda nyata. Hasil penelitian ketebalan jaringan juga tidak menunjukan adanya perbedaan yang nyata antar kelompok. Dengan demikian pemberian asam hyaluronat tidak memberikan dampak negatif terhadap jaringan.
\end{abstract}

Kata kunci: asam hyaluronat, babi, hernia, komposit mesh, polipropilen mesh

\begin{abstract}
The use of mesh can be important methods in hernia abdominalis therapy, because mesh can decrease the incidence of recurrence hernia than the stiching methods. The aim of this research was to study hemogram and tissue response of incisional pig hernia tissue treated with mesh composites and polypropylene with or without hyaluronic acid in histopathology. This research used 11 landrace pigs aged between 3 to 4 months that was divided into 3 groups. First group was using composite mesh (Physiomesh ${ }^{\circledR}$ ). The second group was using polypropylene mesh (Ultrapro ${ }^{\circledR}$ ) that was coated with Hyaluronic acid (Guardic ${ }^{\oplus}$ ). The third group was using polypropylene mesh Ultrapro ${ }^{\oplus}$. This research was started with hernia induction, next was the collection of blood sample, after that was theapplication of mesh, and then followed by harvesting of the tissue and mesh, the last step was making the histopatology slide. The result showed that there was no significancy in Paired T-Test for complete blood count, inflammatory cell in tissue and One-way Annova for inflammatory cell in tissue and collagen thickness. The result also showed that there was no significancy in Paired T-Test for inflammatory cell in tissue except for the macrophage in Group 3 of Ultrapro ${ }^{\oplus}$. Thus the addition of hyaluronic acid did not have a negative effect on the tissue.
\end{abstract}

Keywords: composite mesh, Hernia, hyaluronic acid, pig, polypropylene mesh 


\section{PENDAHULUAN}

Hernia adalah penyembulan abnormal suatu organ melalui suatu pembukaan atau cincin hernia. Adanya cincin hernia menyebabkan organ yang berada di abdomen memasuki area atau ruang subkutan (Jahromi et al., 2009). Pembukaan yang terjadi dapat disebabkan oleh terbukanya bekas luka sayatan operasi, pada bagian pusar atau karena kelemahan otot abdomen (Doctor, 2006). Hernia abdominalis merupakan kasus yang sering ditemukan oleh dokter bedah. Prosedur perbaikan dinding abdomen di Amerika Serikat lebih dari 990 000 kasus per tahun (Montori et al., 2013).

Hernia abdominalis dapat diperbaiki dengan cara penjahitan atau dengan bantuan mesh bedah (Monteiro et al., 2013). Penggunaan metode jahitan sebagai terapi primer maupun sekunder sering menimbulkan kejadian berulang pada hernia abdominalis (Doctor, 2006). Hal ini disebabkan oleh peningkatan tegangan yang memudahkan rupturnya jahitan. Selain itu, adanya iskemia jaringan menyebabkan proses pernyembuhan menjadi lebih lama dan cenderung terjadi hernia berulang (Ober et al., 2008). Penggunaan mesh bedah menjadi metode yang penting untuk terapi perbaikan hernia abdominalis karena dapat menurunkan angka kejadian hernia berulang dan komplikasinya (Poteca, 2013).

Hernia merupakan kasus yang hanya dapat diterapi dengan menggunakan metode bedah. Metode bedah yang dapat dilakukan adalah penjahitan atau pemasangan mesh bedah. Metode penjahitan dapat menimbulkan kejadian hernia berulang karena putusnya benang akibat tegangan dinding abdomen yang terlalu besar atau adanya pergerakan pasien yang berlebihan. Resiko yang ditimbulkan oleh metode penjahitan dapat diatasi dengan menggunakan mesh bedah. Mesh bedah yang beredar di pasaran harganya cukup mahal, sehingga digunakan mesh bedah yang harganya terjangkau namun ditambahkan asam hyaluronat.

Tujuan penelitian ini adalah untuk mempelajari gambaran hemogram (gambaran darah) dan gambaran respon jaringan secara histopatologi pasca terapi dengan mesh bedah polipropilen, dengan atau tanpa asam hyaluronat pada penangan hernia insisional pada dinding abdominalis. Selain itu, hasil penelitian ini diharapkan dapat memberikan kontribusi riset biomaterial dalam penggunaan bahan mesh bedah untuk penanganan kejadian hernia di manusia, dan penggunaan mesh bedah yang harganya terjangkau dengan penambahan asam hyaluronat.

\section{MATERI DAN METODE PENELITIAN}

\section{Waktu dan Tempat Penelitian}

Kegiatan penelitian dilaksanakan pada bulan Januari-Maret 2016. Penelitian dilaksanakan di Laboratorium Bedah Eksperimental Divisi Bedah dan Radiologi, Penyakit Dalam dan Divisi Patologi, Departemen Klinik, Reproduksi dan Patologi, Fakultas Kedokteran Hewan, Institut Pertanian Bogor.

\section{Prosedur Penelitian}

Prosedur penelitian telah mendapatkan persetujuan atas perlakuan etik dari Komite Etik Hewan Institut Pertanian Bogor dengan nomor 672017 IPB. Prosedur penelitian meliputi pengelompokan hewan, aklimatisasi, induksi hernia, pemasangan dan pengambilan mesh, pengambilan darah, pembuatan preparat histopatologi.

\section{Alat dan Bahan}

Alat yang digunakan adalah peralatan bedah minor, peralatan bedah endolaparoskopi, tabung darah dengan EDTA, mesin anesthesia inhalasi, tabung oksigen, mesin darah, Sakura ${ }^{\circledR}$ automatic tissue processor, Sakura ${ }^{\circledR}$ paraffin embedding console, microtome, staining chamber, alat photomicrograph dan perangkat lunak Image $J^{\circledR}$.

Bahan yang digunakan povidone iodine, ketamine, xylazine, Isoflurane ${ }^{\circledast}$, oksigen, mesh bedah Ultrapro ${ }^{\oplus}$ dan Physiomesh ${ }^{\circledast}$, gel asam hyaluronat (Guardic ${ }^{\oplus}$ ), gelas objek, gelas penutup, Buffered Neutral Formalin (BNF) 10\%, pewarna Mayer's Hematoxylin-Eosin dan pewarna MassonTrichome, Entellan ${ }^{\circledR}$.

\section{Hewan Coba}

Penelitian ini menggunakan babi Landrace dengan berat badan 20-30 kg, berumur 3-4 bulan dengan jenis kelamin jantan dan betina. Sebelum perlakuan, babi mengalami aklimatisasi selama satu minggu dan diberi obat cacing Oxfendazole $(4.5 \mathrm{mg} / \mathrm{Kg} \mathrm{bb})$ secara per oral selama tiga hari. Hewan diberi pakan konsentrat dua kali sehari sebanyak $1.5 \mathrm{~kg}$, minum ad libitum dan pembersihan kandang dua kali sehari.

\section{Pengelompokan}

Sebanyak 11 ekor babi dibagi menjadi tiga kelompok perlakuan. Kelompok pertama dengan jumlah 4 ekor diterapi dengan mesh bedah komersial 
(Physiomesh $^{\circledR}$ ), kelompok kedua dengan jumlah 4 ekor diterapi dengan mesh bedah polipropilen (Ultrapro ${ }^{\circledR}$ ) dengan penambahan asam hyaluronat (Guardic $^{\oplus}$ ), dan kelompok ke tiga dengan jumlah 3 ekor hanya menggunakan mesh bedah Ultrapro ${ }^{\circledR}$ tanpa asam hyaluronat.

\section{Induksi Hernia}

Induksi hernia dilakukan dengan metode bedah laparotomi. Hewan dibius dengan ketamine (20mg/Kg bb) dan xylaxine ( $2 \mathrm{mg} / \mathrm{Kg}$ bb), dilanjutkan anesthesi inhalasi untuk maintenance menggunakan isofluran dengan dosis $1.5-3 \%$. Pada bagian abdomen yang akan disayat, dioleskan antiseptika alkohol dan dilanjutkan povidone iodine. Dilakukan penyayatan kulit dibagian medial anterior umbilikal sampai terlihat linea alba, kemudian linea alba disayat namun tidak sampai menyayat peritoneum. Setelah itu kulit dijahit kembali tanpa menjahit sayatan di linea alba. Kemudian babi diberi analgesik Flunixin meglumin $(2 \mathrm{mg} / \mathrm{Kg}$ bb)/hari selama 2 hari i.m, dan antibiotik Amoxicillin ( $1 \mathrm{ml} / 10 \mathrm{Kg}$ bb)/2 hari selama 4 hari i.m, sebagai pengobatan pasca bedah. Selanjutnya babi dikembalikan ke kandang dan dibiarkan hingga terbentuk hernia sampai hari ke-7 (minggu 1).

\section{Pemasangan dan Pengambilan Mesh}

Pemasangan mesh bedah dilakukan dengan metode bedah endolaparoskopi oleh dokter spesialis bedah endolaparoskopi. Setelah dilakukan prosedur standar bedah endolaparoskopi, ditentukan 3 titik di bagian abdominal untuk penempatan probe kamera, clamp dan gunting. Pada titik pertama di cranial umbilicus dimasukkan trocar, kemudian dilakukan tes menggunakan $\mathrm{NaCl}$ fisiologis sebanyak $10 \mathrm{ml}$, lalu diaspirasi. Jika terdapat gelembung udara maka dipastikan trocar sudah masuk ke dalam rongga abdomen. Kemudian ditempatkan probe untuk memasukkan gas $\mathrm{CO}_{2}$ ke dalam rongga abdomen sebanyak $12 \mathrm{mmHg}$. Gas ini menyebabkan rongga abdomen membesar hingga lapang pandang menjadi luas. Selanjutnya probe kamera, clamp dan gunting ditempatkan pada titik masing-masing. Kemudian mesh bedah ditempatkan pada bagian hernia dan difiksasi dengan stapler jaringan pada bagian tepinya. Selanjutnya probe dicabut dan sayatan dijahit kembali. Pengambilan sampel jaringan dilakukan pada saat pemasangan mesh bedah (minggu ke-2) atau 7 hari setelah induksi hernia dengan menggunakan biopsy clamp. Pengambilan sample mesh bedah dilakukan pada 7 hari setelah pemasangannya (minggu ke-3), dengan cara mempreparir jaringan peritoneum menggunakan probe gunting. Sample jaringan dan mesh bedah kemudian difiksasi dalam larutan Buffer Neutral Formalin (BNF) $10 \%$.

\section{Pengambilan Darah}

Pengambilan darah menggunakan syringe $10 \mathrm{ml}$ pada vena cava cranialis. Darah diambil sebanyak 3 $\mathrm{ml}$, kemudian ditempatkan pada tabung dengan EDTA. Desinfeksi area pengambilan darah dilakukan sebelum dan sesudah pengambilan darah. Pengambilan darah dilakukan sebanyak dua kali yaitu pada saat pemasangan mesh bedah (minggu ke-2) dan tujuh hari setelah pemasangan mesh bedah (minggu ke-3).

\section{Pembuatan Preparat Histopatologi}

Jaringan yang telah terfiksasi dalam larutan Buffer Normal Formalin (BNF) 10\%, kemudian didehidrasi dalam alkohol bertingkat 70\% hingga absolut, lalu diinfiltrasi dengan paraffin dan clearing dengan xylol, masing-masing selama 2 jam dalam tissue processor. Kemudian dilakukan embedding, yaitu mencetak jaringan dalam paraffin cair dan dibiarkan hingga paraffin mengeras. Setelah itu jaringan dipotong menggunakan mikrotom dengan ketebalan 4-5 $\mu \mathrm{m}$, dan diletakkan di water bath yang bersuhu $45{ }^{\circ} \mathrm{C}$. Selanjutnya mounting, meletakkan potongan jaringan di atas gelas objek yang telah diulasi albumin, kemudian dikeringkan dalam inkubator dengan suhu $60{ }^{\circ} \mathrm{C}$ selama semalam. Selanjutnya jaringan siap diwarnai dengan pewarnaan Mayer's Hematoksilin-Eosin untuk pengamatan jaringan dan pewarnaan Masson Trichome untuk pengamatan ketebalan kolagen.

\section{Analisis Data}

Analisis data hasil hemogram dan respon sel radang di jaringan sebelum pemsangan dan saat panen mesh bedah menggunakan uji Paired T-Test dengan taraf nyata $5 \%(p<0.05)$. Data respon sel radang di jaringan juga dianalisis dengan uji OneWay Annova dengan taraf nyata $5 \%(p<0.05)$ untuk membandingkan antar perlakuan. Data ketebalan kolagen dianalisis dengan One-Way Annova dengan taraf nyata $5 \%(p<0.05)$. 


\section{HASIL}

\section{Hemogram Babi}

Hasil analisis statistika menggunakan uji Paired TTest terhadap hemogram (Tabel 1) memperlihatkan adanya perbedaan nyata $(\mathrm{p}<0.05)$ pada parameter total white blood cell (WBC), jumlah limfosit dan netrofil, hemoglobin $(\mathrm{Hb})$ dan mean corpusculus volume (MCV) pada kelompok Physiomesh ${ }^{\circledR}$ sebelum dan saat panen. Kelompok Ultrapro ${ }^{\circledR}+$ Guardic $^{\circledR}$ tidak memperlihatkan adanya perbedaan nyata ( $p>0.05$ ) pada seluruh parameter hemogram, kecuali MCV. Kelompok Ultrapro ${ }^{\circledR}$ menunjukkan perbedaan nyata $(\mathrm{p}<0.05)$ hanya pada parameter total WBC dan limfosit. Secara umum nilai hemogram cenderung turun pada saat panen mesh bedah

\section{Gambaran Sel Radang di Jaringan}

Hasil analisis paired t-test jumlah sel radang sebagai parameter peradangan sebelum dan saat panen mesh bedah tidak berbeda nyata $(p>0.05)$ pada jumlah netrofil, limfosit dan sel raksasa (Gambar 1). Jumlah makrofag kelompok Physiomesh ${ }^{\circledR}$ berbeda nyata $(p<0.05)$ dibandingkan dengan Ultrapro $^{\circledR}$ (Gambar 1).

Hasil analisis perbandingan jumlah sel radang netrofil, limfosit, makrofag dan sel raksasa antar kelompok mesh bedah tidak berbeda nyata ( $p>0.05)$. Jumlah netrofil kelompok Physiomesh ${ }^{\circledR}$ paling tinggi, diikuti kelompok Ultrapro ${ }^{\circledast}+$ Guardic $^{\circledR}$ pada urutan kedua dan terakhir kelompok UItrapro ${ }^{\oplus}$. Jumlah limfosit tertinggi pada kelompok Ultrapro $^{\circledast}+$ Guardic $^{\circledR}$, diikuti kelompok Physiomesh ${ }^{\circledR}$ pada urutan kedua, dan terakhir kelompok UItrapro ${ }^{\circledast}$. Jumlah makrofag paling tinggi pada kelompok Ultrapro ${ }^{\oplus}+$ Guardic $^{\circledR}$, diikuti kelompok Ultrapro $^{\circledast}$ dan Physiomesh ${ }^{\circledast}$, sedangkan jumlah tertinggi sel raksasa ditemukan pada kelompok Ultrapro $^{\circledast}$ yang diikuti kelompok Ultrapro ${ }^{\circledR}+$ Guardic $^{\circledR}$ dan terakhir Physiomesh ${ }^{\circledR}$. Hasil analisis jumlah limfosit dari ketiga mesh bedah tidak berbeda nyata $(p>0.05)$.

\section{Ketebalan Kolagen}

Hasil analisis statistik pada ketebalan kolagen di jaringan antar perlakuan tidak berbeda nyata $(p>0.05)$.

Tabel 1 Perbandingan hemogram hernia insisional babi pasca terapi mesh bedah polipropilen dengan atau tanpa asam hyaluronat sebelum dan saat panen

\begin{tabular}{|c|c|c|c|c|c|c|}
\hline \multirow{3}{*}{ Parameter Darah } & \multicolumn{6}{|c|}{ Mesh bedah } \\
\hline & \multicolumn{2}{|c|}{ Physiomesh $^{\circledast}$} & \multicolumn{2}{|c|}{ Ultrapro $^{\circledast}+$ Guardic $^{\circledast}$} & \multicolumn{2}{|c|}{ Ultrapro $^{\circledast}$} \\
\hline & Sebelum & Panen & Sebelum & Panen & Sebelum & Panen \\
\hline $\mathrm{WBC}\left(10^{3} / \mu \mathrm{L}\right)$ & $21.35 \pm 2.63^{a}$ & $16.62 \pm 3.82^{b}$ & $13.00 \pm 3.79$ & $14.65 \pm 2.65$ & $15 \pm 3.68^{a}$ & $13.97 \pm 3.47^{b}$ \\
\hline Limfosit $\left(10^{3} / \mu \mathrm{L}\right)$ & $10.99 \pm 1.05^{a}$ & $8.46 \pm 1.81^{b}$ & $6.45 \pm 1.34$ & $5.82 \pm 1.75$ & $5.48 \pm 2.32^{b}$ & $6.80 \pm 2.76^{b}$ \\
\hline Monosit $\left(10^{3} / \mu \mathrm{L}\right)$ & $1.65 \pm 0.01$ & $0.23 \pm 0.13$ & $0.33 \pm 0.32$ & $0.44 \pm 0.54$ & $0.63 \pm 0.87$ & $0.09 \pm 0.03$ \\
\hline Neutrofil $10^{3} / \mu \mathrm{L}$ ) & $10.19 \pm 1.87^{a}$ & $7.92 \pm 2.12^{b}$ & $6.43 \pm 3.23$ & $8.38 \pm 3.82$ & $9.72 \pm 3.66$ & $7.08 \pm 4.77$ \\
\hline Eosinofil $10^{3} / \mu \mathrm{L}$ ) & $0 \pm 0.00$ & $0 \pm 0.00$ & $0 \pm 0.00$ & $0 \pm 0.00$ & $0 \pm 0.00$ & $0 \pm 0.00$ \\
\hline Basofil $\left(10^{3} / \mu \mathrm{L}\right)$ & $0 \pm 0.00$ & $0 \pm 0.00$ & $0 \pm 0.00$ & $0 \pm 0.00$ & $0 \pm 0.00$ & $0 \pm 0.00$ \\
\hline Limfosit (\%) & $51.5 \pm 3.79$ & $51.25 \pm 4.38$ & $51.6 \pm 15.35$ & $41.8 \pm 17.48$ & $36.07 \pm 15.71$ & $51.23 \pm 22.43$ \\
\hline Monosit (\%) & $0.78 \pm 0.13$ & $1.35 \pm 0.58$ & $0.9 \pm 0.46$ & $2.67 \pm 2.91$ & $3.47 \pm 4.53$ & $0.63 \pm 0.15$ \\
\hline Neutrofil (\%) & $47.48 \pm 3.81$ & $47.4 \pm 3.84$ & $47 \cdot 5 \pm 15 \cdot 32$ & $55.53 \pm 14.65$ & $60.4 \pm 11.17$ & $48.1 \pm 22.30$ \\
\hline Eosinofil (\%) & $0 \pm 0.00$ & $0 \pm 0.00$ & $0 \pm 0.00$ & $0 \pm 0.00$ & $0 \pm 0.00$ & $0 \pm 0.00$ \\
\hline Basofil (\%) & $0 \pm 0.00$ & $0 \pm 0.00$ & $0 \pm 0.00$ & $0 \pm 0.00$ & $0 \pm 0.00$ & $0 \pm 0.00$ \\
\hline $\operatorname{RBC}\left(10^{6} / \mu \mathrm{L}\right)$ & $7.15 \pm 0.66$ & $6.2 \pm 0.88$ & $6.44 \pm 0.44$ & $5.93 \pm 0.20$ & $6.74 \pm 0.14$ & $5.73 \pm 1.00$ \\
\hline $\begin{array}{l}\text { Hemoglobin } \\
\text { (Hb) (g/dL) }\end{array}$ & $10.43 \pm 0.43^{a}$ & $9.18 \pm 1.10^{b}$ & $9.47 \pm 0.85$ & $8.4 \pm 0.26$ & $10.13 \pm 0.61$ & $9.43 \pm 0.25$ \\
\hline $\begin{array}{l}\text { Hematokrit } \\
(\mathrm{Hct})(\%)\end{array}$ & $36.52 \pm 0.44$ & $31.04 \pm 4.93$ & $33.37 \pm 2.04$ & $29.8 \pm 1.45$ & $36.24 \pm 2.33$ & $29.71 \pm 4.78$ \\
\hline$M C V(f / L)$ & $51.75 \pm 4.5^{a}$ & $50.25 \pm 4.86^{b}$ & $52.00 \pm 1.00^{a}$ & $50.33 \pm 1.15^{b}$ & $53.66 \pm 1.53$ & $51.67 \pm 1.53$ \\
\hline $\mathrm{MCH}(\mathrm{pg})$ & $14.65 \pm 1.24$ & $14.93 \pm 1.08$ & $14.67 \pm 0.32$ & $14.17 \pm 0.12$ & $15.1 \pm 0.00$ & $16.87 \pm 2.74$ \\
\hline $\mathrm{MCHC}(\mathrm{g} / \mathrm{dL})$ & $28.58 \pm 0.92$ & $29.8 \pm 1.93$ & $28.3 \pm 2.96$ & $28.2 \pm 0.61$ & $28.03 \pm 0.68$ & $32.43 \pm 4.99$ \\
\hline
\end{tabular}

Keterangan: Superscript yang berbeda pada baris yang sama menunjukkan perbedaan nyata $(\mathrm{p}<0.05)$ 


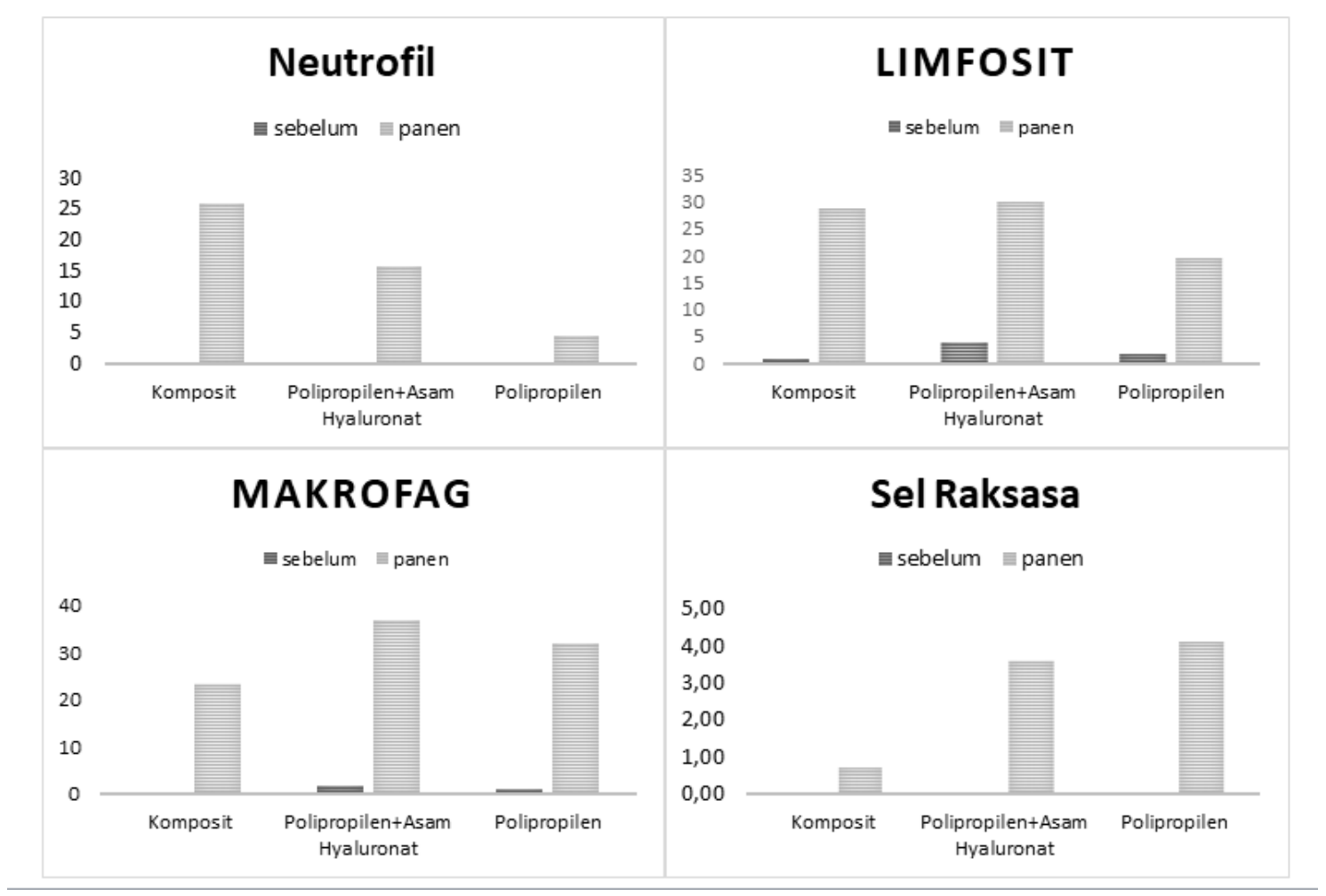

Gambar 1 Perbandingan jumlah sel radang netrofil, limfosit, makrofag dan sel raksasa di jaringan hernia insisional babi yang diterapi mesh bedah polipropilen dengan atau tanpa asam hyaluronat sebelum dan saat panen

kolagen kelompok Ultrapro ${ }^{\circledR}+$ Guardic $^{\circledast}$ paling tebal diikuti oleh Physiomesh ${ }^{\oplus}$ dan Ultrapro ${ }^{\circledR}$. Hasil analisis statistik ketebalan kolagen di jaringan menunjukkan tidak ada perbedaan yang nyata $(p<0.05)$ antar perlakuan, namun kelompok Ultrapro ${ }^{\circledR}+$ Guardic $^{\circledR}$ memiliki kolagen yang lebih tebal dibandingkan kedua mesh bedah lainnya.

Hal ini memperlihatkan kemampuan Ultrapro ${ }^{\circledR}+$ Guardic $^{\circledast}$ mempercepat persembuhan yang lebih baik dibandingan dengan kedua kelompok mesh bedah lainnya dalam waktu yang sama. Hasil perhitungan ketebalan kolagen dapat dilihat pada Gambar 2 .

\section{PEMBAHASAN}

Penurunan nilai hemogram pada total WBC dan diferensial leukosit mengindikasikan sel darah putih tersebut telah berpindah dari sirkulasi menuju ke jaringan sebagai bentuk respon tubuh terhadap adanya benda asing (Martins et al., 2015). Penggunaan mesh bedah ringan polipropilen menginduksi reaksi inflamasi dan memicu persembuhan yang cepat (Melman et al., 2011). Neutrofil merupakan salah satu jenis leukosit yang akan berpindah dari sirkulasi ke jaringan jika terjadi inflamasi (Kolackzakowska \& Kubes, 2013). Monosit adalah sel darah putih yang terlibat dalam sistem monosit-makrofag, akan bermigrasi menuju lokasi peradangan dan berdiferensiasi menjadi makrofag (McGavin \& Zachary, 2007). Sistem monosit-makrofag pada reaksi peradangan akut, sangat berperan penting dalam persembuhan jaringan (Martins et al., 2015).

Ultrapro ${ }^{\circledR}$ merupakan salah satu mesh bedah komersial yang memiliki benang monofilamen dengan kerapatan rendah atau pori besar dengan ukuran $4 \mathrm{~mm}$. Mesh bedah ini terdiri atas 2 lapisan, lapisan polipropilen berkerapatan rendah yang dilapisi poliglecaprone pada lapisan kedua. Mesh bedah ini terserap tubuh dalam waktu sekitar 90 hari (Aramayo et al., 2013). Mesh bedah dengan ukuran pori lebih dari satu mm memiliki kemampuan lebih besar menarik sel radang, sebagai bentuk pertahanan dirinya di jaringan. Mesh bedah yang digunakan pada penelitian ini memiliki pori lebih dari 1 $\mathrm{mm}$, sehingga sel radang netrofil, limfosit, makrofag dan sel raksasa sangat mungkin berada di ketiga kelompok tersebut. Keberadaan sel-sel radang bukanlah hal yang negatif, namun untuk mengurangi 


\section{KETEBALAN KOLAGEN}

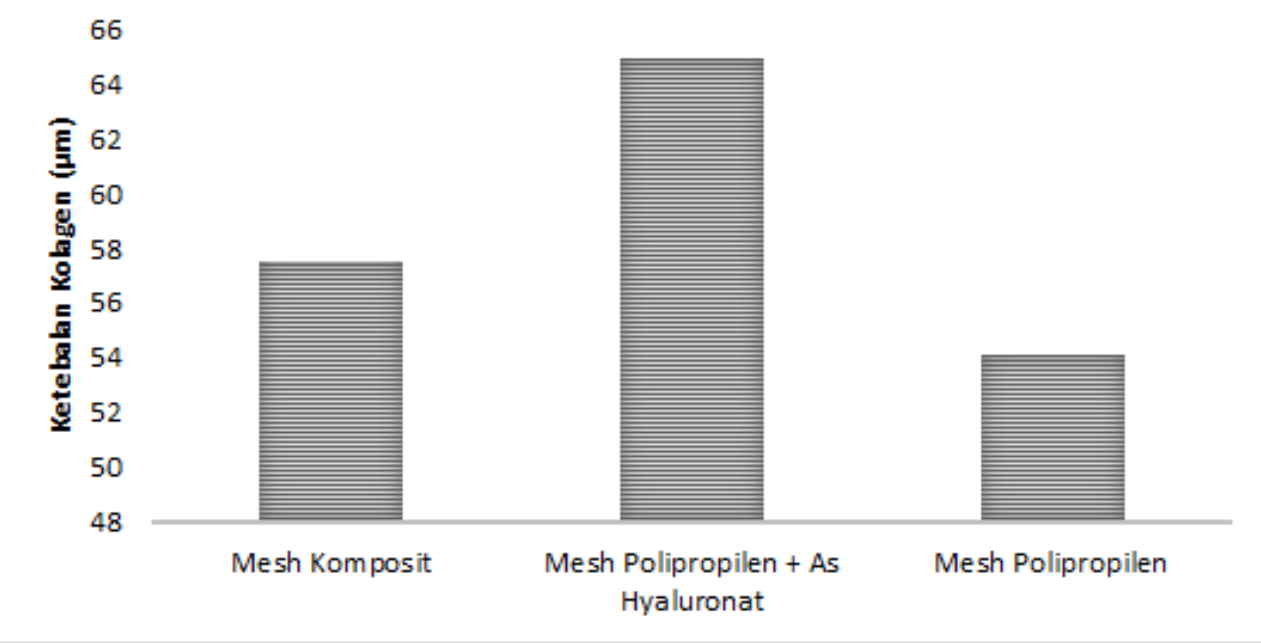

Gambar 2 Perbandingan ketebalan kolagen pada jaringan hernia insisional babi pasca terapi dengan mesh bedah polipropilen dengan atau tanpa asam hyaluronat

kemungkinan infeksi (Brown \& Finch, 2010).

Luka yang dialami oleh hewan coba merupakan luka akut. Hal ini sesuai dengan pernyataan Velnar et al. (2009), luka akut berkisar antara 5-10 hari bahkan sampai 30 hari. Komponen peradangan yang hadir di daerah luka adalah leukosit dan plasma protein. Netrofil adalah leukosit yang pertama kali menuju jaringan yang rusak untuk melakukan fagositosis. Fungsi utama netrofil adalah mencegah infeksi dengan menghancurkan dan menghilangkan bakteri, benda asing dan jaringan rusak melalui fagositosis. Netrofil muncul pada 24-36 jam setelah terjadi luka karena adanya agen chemoattractive seperti TGF- $\beta$, komplemen C3a dan $C_{5} \alpha$, dan peptida formylmethionyl yang dihasilkan oleh bakteri dan platelet. Setelah tugasnya selesai netrofil akan hancur dengan mekanisme apoptosis sehingga tidak akan merusak jaringan di sekitarnya (Velnar et al., 2009).

Ketiga mesh bedah memiliki bahan pelapis polyglecaprone yang berfungsi untuk menurunkan resiko infeksi. Physiomesh ${ }^{\circledR}$ juga memiliki lapisan polidioxanone yang dilapisi oleh monocryl untuk menahan pembentukan perlekatan dengan organ dan menurunkan pembentukan seroma (Kalaba et al., 2016). Ultrapro ${ }^{\circledR}$ + Guardic ${ }^{\circledR}$ merupakan Ultrapro ${ }^{\circledR}$ yang ditambahkan asam hyaluronat (Guardic ${ }^{\circledR}$ ). Asam hyaluronat berfungsi sebagai bakteriostatik (Sezer \& Cevher, 2011).
Kolagen merupakan komponen utama pada matriks ekstraseluler yang terdiri atas 20 tipe dan berperan penting mempertahankan elastisitas dan ketegangan suatu jaringan (Sezer \& Cevher, 2011). Kolagen merupakan protein utama lapisan jaringan fascia dinding abdomen (Franz, 2008). Serat kolagen dibentuk oleh fibroblast dan sel jaringan ikat lainnya. Reaksi hidroksilasi intraseluler membentuk hidroksilisin dan hidroksiprolin yang merupakan komponen penting dalam pembentukan dan stabilitas kolagen yang terbentuk menjadi triple helix. Pada jaringan ekstraseluler, enzim lysil oksidase merupakan perantara proses cross-lingking yang akan membuat formasi kolagen fibril dan serat yang kuat dan stabil (Radu et al., 2015).

Asam hyaluronat merupakan biopolimer alami yang terdiri dari D-Glucoronic acid dan 2-acetamido-2deoxy-D-glucose yang banyak terdapat pada jaringan penghubung dan cairan synovial mamalia. Asam hyaluronat berinteraksi dengan protein, proteoglycans, growth factor, dan komponen jaringan yang disebut biomolekul, yang berperan penting dalam persembuhan berbagai tipe luka. Interaksi ini berperan penting dalam percepatan perbaikan jaringan dan persembuhan luka (Sezer \& Cevher, 2011).

Limfosit adalah sel radang terakhir yang datang dalam proses peradangan. Limfosit hadir akibat adanya interleukin-1, komplemen dan Imunoglobulin-G 72 jam setelah terjadinya perlukaan (Velnar et al., 2009). 
Perbedaan jumlah makrofag dan sel raksasa pada setiap kelompok mesh bedah dapat disebabkan oleh perbedaan material mesh yang digunakan. Material Physiomesh $^{\circledR}$ bertujuan menurunkan resiko perlekatan dengan organ di sekitarnya, sehingga Physiomesh ${ }^{\circledast}$ memiliki tingkat penerimaan jaringan yang lebih tinggi dibandingkan Ultrapro ${ }^{\oplus}+$ Guardic $^{\circledast}$ dan Ultrapro ${ }^{\circledR}$. Penerimaan Physiomesh ${ }^{\circledR}$ di jaringan paling baik, ditunjukkan dengan rendahnya jumlah makrofag dan sel raksasa. Mekanisme keberadaan makrofag di jaringan dimulai dari keluarnya monosit dari sirkulasi. Makrofag merupakan bagian dari fase inflamasi akhir yang hadir 48-72 jam setelah luka terjadi. Makrofag muncul pada luka sebagai penerus proses fagositosis. Makrofag tertarik ke jaringan oleh banyak agen chemoattractive termasuk di dalamnya adalah faktor pembeku, komponen komplemen, sitokin-sitokin seperti PDGF, TGF- $\beta$, Leukotriene $\mathrm{B}_{4}$ dan faktor platelet IV (Velnar et al., 2009). Makrofag berfungsi melakukan fagositosis terhadap jaringan yang rusak dan debris, serta mensekresikan beberapa growth factor (Franz, 2008). Makrofag memiliki umur yang lebih panjang dibandingkan netrofil, dan akan bertahan lebih lama pada $\mathrm{pH}$ yang lebih rendah (Velnar et al., 2009). Implantasi suatu bahan di jaringan akan menginduksi respon terhadap benda asing, dan makrofag akan hadir sebagai respon melawan benda asing tersebut. Pada saat makrofag tidak mampu memfagositosis benda asing, maka makrofag akan melakukan fusogenik. Fusogenik merupakan kemam-puan makrofag untuk bergabung dan membentuk sel yang lebih besar atau yang disebut sebagai sel raksasa. Dalam hal ini disebut juga sebagai sel raksasa tipe benda asing (Jay et al., 2010).

Penambahan asam hyaluronat pada mesh bedah polipropilen Ultrapro ${ }^{\oplus}+$ Guardic $^{\circledR}$ dalam waktu tujuh hari tidak memberikan dampak negatif terhadap gambaran hemogram, menginduksi hadirnya sel radang netrofil, limfosit, makrofag dan sel raksasa yang merupakan respons fisiologis terhadap adanya benda asing, dan memperlihatkan pembentukan kolagen yang lebih baik dibandingkan dengan kelompok Physiomesh ${ }^{\circledR}$ dan Ultrapro ${ }^{\circledR}$.

"Penulis menyatakan tidak ada konflik kepentingan dengan pihak-pihak yang terkait dalam penelitian ini"

\section{DAFTAR PUSTAKA}

Aramayo ALG, Filho GJL, Barbosa CA, Amaral VF, Costa LA. 2013. Abdominal wall healing in incisional hernia using different biomaterials in rabbit. Acta Cirurgica Brasileira vol 28 (4): 307.

Brown CN, Finch JG. 2010. Which mesh for hernia repair. Ann. R. Col.I Surg. Engl. vol 92: 272-278.

Doctor HG. 2006. Evaluation of various prosthetic materials and newer meshes for hernia repairs. Journal of Minimal Access Surgery vol. 2 (3): 110116.

Franz MG. 2008. The biology of hernia formation. Surg. Clin. North. Am. 88(1):1-vii.

Jahromi AR, Nazhvani SD, Gandmani MJ, Mehrshad S. 2009. Concurrent bilateral inguinal and umbilical hernias in a bitch-a case report. Veterinarski Arhiv 79(5): 517-522.

Jay SM, Skokos SA, Zeng J, Knox K, Kyriakides TR. 2010. Macrophage fusion leading to foreign body giant cell formation persists under phagocytic stimulation microspheres in in vitro and in vivo in mouse models. J Biomed Mater Res A 93(1): 189199.

Kalaba S, Gerhard E, Winder JS, Pauli EM, Haluck RS, Yang J. Design strategies and applications of biomaterials and devices for hernia repair. Bioactive Materials 1: 2-17

Kolackzakowska E, Kubes P. 2013. Neutrophil recruitment and function in health and inflammation. Immunology vol. 13: 159-175.

Martins AF, Borges NC, Coutinho PV, Lemes AR, da Silva AS, Barbosa RK, Paulo NM. 2015. Acute systemic response to intraperitoneal implantation of polypropylene mesh/chitosanbased film composite in pigs. Acta Cirúrgica Brasileira 30 (10):675-680.

McGavin MD, Zachary JE. 2007. Pathologic Basis Veterinary Disease. $4^{\text {th }}$ ed. Missouri (US): Elsevier.

Melman L, Jenkins ED, Hamilton NA, Bender LC, Brodt MD, Deeken CR, Greco SC, Frisella MM, Matthews BD.2011. Histologic and biomechanical evaluation of a novel macroporous polytetrafluoroethylene knit mesh compared to lightweight and heavyweight polypropylene mesh in a porcine model of ventral incisional hernia repair. Hernia 15(4):423431

Monteiro GA, Delossantos Al, Rodriguez NL, Patel P, Franz MG, Wagner CT. 2013. Porcine incisional hernia model: Evaluation of biologically derived intact intracellular matrix repairs. Journal of Tissue Engineering vol. 4 (2041731413508771): 1-13. 
56 | Vibowo et al.

Radu P, Bratucu M, Garofil D, Goleanu V, Popa F, Strambu V. 2015. The role of collagen metabolism in the formation and relapse of incisional hernia. Chirurgia No 3 110: 224-230.

Sezer AD, Cevher E. 2011.Biomaterials Application for Nanomedicine. Ed Rosario Pignatello. In Tech: Kroasia. Hal: 383-441
Velnar T, Bailey T, Smrkolj V. 2009. The wound healing process: An overview of the cellular and molecular mechanism. The Journal of International Medical Research vol. 37(5): 15281542. 